\title{
脳動脈瘤の治療・過去，現在，将来
}

\author{
鈴 木 二 郎
}

\section{Treatment of Cerebral Aneurysms in Past, Present and Future}

Jiro SuzuKi, M.D.

Emeritus Professor of Tohoku University Ohizumi Memorial Hospital, Zao, Japan

私の脳動脈瘤の経験は, 勿論, 先輩脳外科医の多くの脳 動脈瘤の研究の仕事に基づき経験し，また勉強させて頂い たことばかりなのであり, 私の話をする前に世界での脳動 脈瘤の手術の歴史を簡単に述べたい.

\section{1. 歴史}

さて，1927年，偉大なるEgas Moniz がヒトでの脳血管 撮影を創始してから，1933年 Dottが angiography で発見 して開頭して IC の bifurcationの動脈瘤に muscle wrapping を行ったのが動脈瘤の直接手術の最初と言われてい る. 1937年 Day は Pcom aneurysm の clipping に成功して いる.しかし，この例は脳血管撮影による手術ではなく oculomotor N. palsy という神経学的所見によって決断し て手術した症例である。そしてその頃から米国やヨーロッ パでは動脈瘤の外科的方法の論文が多くなり, 次第に動脈 瘤の手術が発展していった：そして1966年の Locksleyら の USA の co-operative study で3,260例の諸データーが集 計された。

さて, 1959年, 34歳の私は第 8 回のラテンアメリカ脳外 科学会に出席のために, 南米チリ・サンチアゴの Prof. Asenjo の所に出かけ, その後南米各地で脳外科的刺激を 与えられて䚻ってきた。 その一つはProf. Carrea の中大脳 動脈瘤の手術で, ブエノスアイレスの子供病院で初めての
手術ということで熱心に見学した. 彼の手術はきれいに動 脈瘤を出して, 動脈瘤の neckではなく domeの上から一 本の銀クリップを neckに向けて掛けた。「Jiro，これで十 分だろう.」というのだが, 誰が見ても不十分であり, 私 はそれでは不十分ではないかと発言した. 彼はもう一本平 行的に銀クリップをかけ，私にまた聞いた。私は，それま で aneurysmの手術を見たことがないので，これでいいの かと,いい手術であると言ったことを思い起される.

Chile の Institute は既に Professor Asenjo は opeをして いなかった. Professor Valladaresの手術を見る機会が多 く, Valladaresは私の手術に大きな影響を与えた。それま で私は頭部の皮切は上向きに曲った馬蹄型の, あるいは真 っすぐの皮切しかやれないものと思っていたが, Valladares の temporal lobe resectionを見て, その皮切は下向 きの全く逆な孤状の皮切なのに驚き, 皮切はどうでもでき るのだと，その自由さから脳外科医としての悟りを得たよ うにも思った。

そして，1961年の 5 月27日, 恩師の桂先生からやっと手 術の許可を受け，このV Valladares が priority をもってい る，そして私が命名した “keel form incision”で, PcomA の16歳の男性の手術を私の最初の動脈瘤の経験として 行うことができた。 その例は, 私の友人の渡辺晃の低体温 麻醉の研究を利用させてもらって低体温で, $27^{\circ} \mathrm{C} て ゙$ 行った。

東北大学名誉教授, 大泉記念病院 脳神経外科 
しかし術中，まだ動脈瘤が見えないうちに致命的な rupture をして大変な手術になった。しかしやっと neck の clipping に成功した，ところで，一昨年42歳となったこの 患者さんが子供さん 2 人を連れて私の前に現れた．医者の 冥利であった。

それから一昨年, Dr. Fox の脳動脈瘤の手術書を見たと き, 私の日本語の1967年の発表の multiple aneurysmの皮 切の図を日本語のまま彼の本に大きく載っているのを見た が，それも私がValladaresの皮切からヒントを受けての 各種の皮切だった。私は1961年に第一例目の手術に成功し てから次第に経験が多くなり，1969年の第 4 回のWFNS のニューヨークで脳動脈瘤の手術に関して発表をした。そ れらはすべて低体温麻酔を用いて，私の裸眼で，250例の 中 216 例 $85.8 \%$ を直接手術し，follow-up 時までに18例が死 亡し $8.3 \%$ の死亡率という発表であり，脳動脈瘤のテーマ での私の最初の国際会議発表である。

1970年 3 月，日本外科学会で脳動脈瘤について特別講演 を指名され，その機会に日本の全国の脳外科施設にアン ケートを出して，日本全国的な動脈瘤についての調査をさ せて頂いた．そしてその総数が3,458例，3,899個というこ とで日本のその時代での状況が把握できた．私は316例で あり，日本で最も多く動脈瘤を経験していたことにも驚か されたのである ${ }^{4)}$.

それまでの症例は低体温麻酔で手術を行ってきたが，こ れは極めて困難な麻酔で，低温にするため，また復温させ るためにも時間がかかり，心停止などの重篤な合併症もあ り，この麻酔に代わる脳血流遮断時間を延長する方法はな いものかと常に考えていた，たまたま50歳の女性の MCA aneurysmの患者さんの手術をすることになったが，彼女 は重症心疾患を合併していた。麻酔医は「低体温麻酔は不 可能.」というのである．私はそれまで300例の手術の経験 がある．私は常温麻酔で十分手術可能という誤った自信で 手術を行ったところが術中に絶望的な脳動脈瘤の破裂を してしまい， $\mathrm{M}_{1} ， \mathrm{M}_{2}$ の流入流出動脈の全部に temporary clip をおいて血流遮断をして動脈瘤を処理せざる得なくな り，血流遮断が50分以上になってしまった，常温で血流遮 断50分の遮断になってしまった。私はまったく見込なしと いうことで，翌朝早くその患者さんを見に行ったが，患者 さんは意識も正常で麻痺もなく，全く元気であり，間もな く退院した．私は 5 分で血流遮断が䭾目という医学の常識 に反して50分以上の遮断でもいい結果を得たことを，我々 が人工的にこの患者さんに何かをやっていた結果ではない かと気がっき, 術前・術中・術後に行ったすべての処置を 検討した．私は術中に脳容積を縮小させるために用いた $20 \%$ mannitol がどうも脳血流遮断時間を延長させた原因 ではないのかと，困難な低体温麻酔に代わる方法ではない
のかとその後動物実験を始めることになった。

しかし，薬効を確実にするためには理想的な cerebral infarction の実験動物をまず造らなくてはならない，それ は大きな動物で, 同じ脳の場所に同じ程度の, 同じ大きさ の infarction focus を高頻度に造ることができるもので, しかも長期間動物が生存するということが必要なのである. 我々は犬で，その一側側頭から脳を傷つけないように顕微 鏡下に脳底部ウイルス輪に流入流出するすべての血管を遮 断できることに次第に気がついて，脳底の血管の閉塞をそ の順列組合せにすることによって種々の型の cerebral infarctionのモデルも造ることができた.

このモデルを用いて，全脳血流を心臟系の血流から完全 に隔離し，脳血流の方は一つの perfusion pump を迴して 自由に，脳血流量をコントロールできるモデルを造ること に成功し，脳波，あるいは脳浮腫の程度を見て薬効の判定 を確実にできるようになった，すなわち一側の中大脳動脈 瘤に細いカニューレを挿入して，ここにポンプからの血流 を流入させ，ある組合せでの脳底血管を閉塞すれば，ポン プを迴すことによって随意に脳血流量をコントロールでき るもので，ポンプを止めれば，脳血流はゼロになるのであ る (Fig. 1).

最初, 脳血流量を術前の計量した量としてポンプを回転 させ脳波を記録し始め，30分後ポンプを完全に停止し，脳 波も完全に平坦になることを確認し，ただちに元の血流量 に戻し，脳血流はポンプでコントロールされているものと 確認し，その後30分間に体循環内に mannitol などの試験 薬戍を注入して今度は脳血流を $10 \%$ に減少させ，そのそ血 状態を 1 時間継続させその後 $100 \% に \mathrm{CBF}$ を復元して, 3 時間脳波を記録しながら 3 時間目の脳波の状況を 4 段階 に分けて薬効を決定するのである(Fig. 2).

薬剤の投与をしなかったモデルやリンゲルソリューショ ンの投与をしたモデルでは，全く脳波は flatである。 $20 \%$ mannitol 単味では，脳波の回復は見られる。 それに人工 血液を加えると回復はよりいいのである。その後は動脈瘤 の手術には $20 \%$ の mannitol を用いて, 動脈瘤自身を剩離 する前に必ず流入・流出動脈に一時的クリップを用いて閉 鎖して，次いで動脈瘤の手術を行うようになった。20\% mannitol の使用を，私が発表した方法で厳守すれば術後 障害を起こしたと思われるものはなかった．

それによって破裂急性期の手術の場合にも安全に，早く 確実に動脈瘤を処理できるようになった，血流遮断によっ て動脈瘤内の血圧がゼロになるので, 動脈瘤をピンセット でつまんで剥離することができ，その後側も十分に観察で きるので，動脈瘤の後側の娘動脈瘤を見逃すこともなく， 後側の重要な枝を閉塞する危険もなくなり, neckの十分 な処置ができるようになって，手術成績は向上していった． 


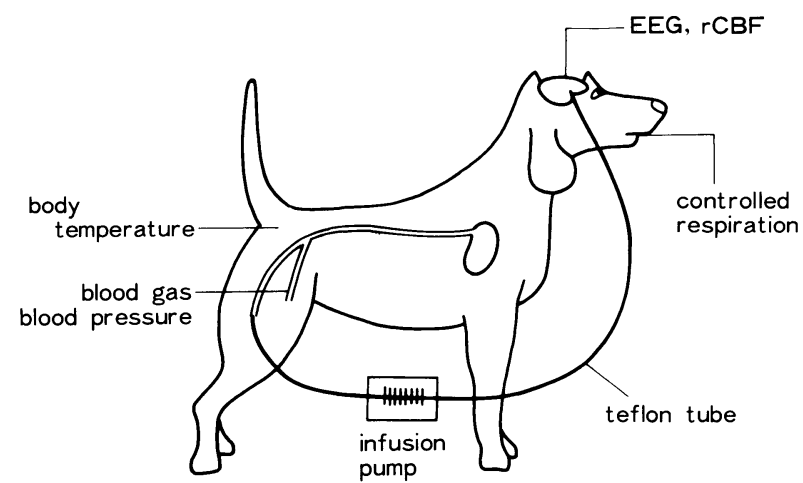

Fig. 1

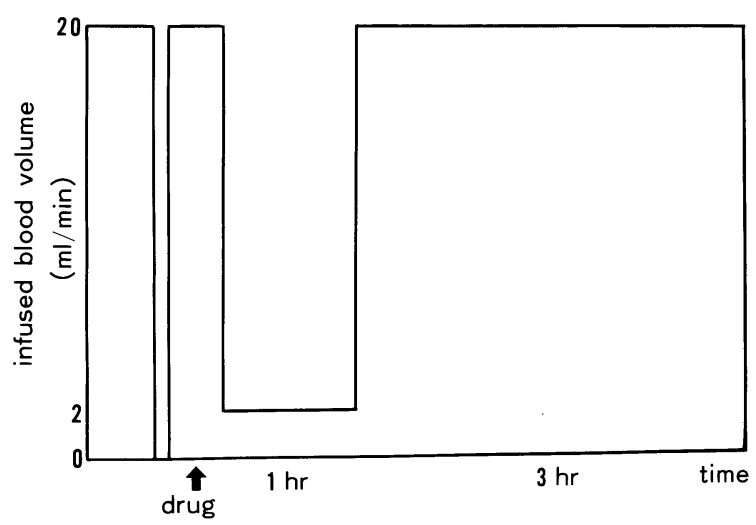

Fig. 2

また，私が考案した temporal clip は長くて便利で，プ レート圧 $40 \mathrm{~g}$ 程度であり, 内膜に傷をつけない. そして temporal clip の解除もどんな方向からも容易に除去する ことができる．この方法を用いることにより成績が良くな り, 内科の先生からも信頼されることになって症例は年々 増加し，1975年の 6 月 9 日には私自身で1,000例目の直接 手術を行うことができたのである．私は健康であり，すぐ れたスタッフに助けられて行うことができたものと感謝し ている.

その1,000例を，1961年の第一例目から脳動脈瘤に対す る手術の私の policy と technique がほぼ一定になってきた 1970年までの10年間のグループと, それ以後の1975年まで の 2 つグループに分けて手術成績を比べる. 勿論どの破 裂から手術までの時間別のものでも成績は向上しており, 特に破裂48時間以内の手術例では成績が極めて良くなって いたのである．また，この1,000例を各方面より検討して 多くの新しい知見も得たのである．例えば動脈瘤の部位で は欧米の発表と, あるいは日本全国でのものと比べ, ほぼ 同じ傾向である. 破裂動脈瘤の再破裂の時期は 3 日以内に 最も多い，第一日目の 6 時間以内に最も多いということが 分かってきている。そして14日目以後にも再破裂に注意し
なければならない. spasmによって症状を起こしてくるの は破裂後 4 日から14日目に限って出現することも分かって きた。 そして，この1,000例の手術経験を教室の協力で各 方面から検討して，英文の 100 論文を一冊にまとめて 800 ページの本として1979年，すなわち 4 年間を使ってまとめ て発行したのである ${ }^{6)}$.

Professor Drake は以前,「Jiro，早期手術などというこ とは絶対言わないほうがいい，お前の言動によって日本中 に犠牲者が累々としてくるぞ.」と何回も言われた。しか し早期手術をいろいろと工夫してみると，決してその成績 は悪くない，要するに， late operationは単に動脈瘤の再 破裂を防ぐだけであるが，早期手術には救命の目的もあり， また血管攣縮を少なくする，そして脳室ドレナージによっ て脳圧のコントロールもついでにできる．脳をいい状況の もとで社会に復帰させることができるのである122)5.

また, rerupture は最近の我々の研究では 6 時間内に最 も多く起こるので，最近ではその間は血圧のコントロール を厳重にしてただ安静にしておくこと，その後に初めて CT や血管撮影の検査を行い, 手術の適応であれば手術を することにしている，手術のゴールデンタイムは20時間以 内で，それ以後になるとやはり静脈血流の stagnation が 強くなりがちとなる.

一方, SAH の血管攣縮の原因も次第に分かってきた. クモ膜下を走っている太い動脈にこびり付いている血腫が 脳内で 3 日間放置されると溶血して oxyhemoglobin が析 出されてそれが原因となって vasospasm が起こってくる. その clotを急性期にきれいに除去すればvasospasm を防 ぐことができるのである.

また，破裂後の脳圧のコントロールを早期に側脳室ドレ ナージによって行えば，管理も容易に行えることになり抜 去不能のものではシャントを行うことにより NPH を防ぐ ことができるのである。しかし, late operationよりも早 期手術は困難であることは事実であり, 術中は必ず premature rupture がくると思って手術を行うことが必要であ る。また，vasospasmを防ぐために clotを除去するとき にSylvian fissure の静脈を, あるいは深い所の静脈を損 傷してしまい，更に大きな出血を起こすこともあるので， その止血の仕方を考えてやらなければならない. 静脈出血 がひどいときは頭の位置を高くすることによって静脈出血 をコントロールができる.

また, 深い所の静脈の損傷はしばしば致命的になる，脳 にうっ滞している血流を更に脳べラによって圧迫して, 深 部に出血がくる．また，動脈硬化のひどい患者の場合にも 注意しなければならない. 少しの力で細い枝が抜けやすい. それでその出血をコントロールする方法も知っておかなけ ればならない. また動脈硬化部の上の temporary clip はそ 
の効果が得られないばかりか, 内膜損傷によって血管の閉 塞の起こることもあり注意しなくてはならない. また， aneurysm の neck の処置で, 流入流出動脈の kink が起こ りやすく, 術後に合併症を起こしてしまうので注意しなく てはならない.

しかし最も大切な注意をしなくてはならないのは, vasospasmの予測，予防，治療についての知識である．血 管にこびり付いた血腫がvasospasm を引き起こすが，開 頭前に vasospasm を起こすほどの clotであるかどうか, そのまま放置しても spasm を起こさないものかという判 断も必要である。

同じ症例で連日 CTを撮影してみると, HDA は急激に 消退するものではまず spasm は起こらない. ところが， HDA がそのまま経過する clot では $99 \%$ その部分の血管に spasm を起こすのである. すなわち, Hounsfield のNo. を 注意深く考え，どの部分の clot は術中にきれいにしなく てはならないとか，それが両側であれば両側を開頭しなけ ればならないという訳になる。

とにかく半球間の clot, Sylvian fissure の両側では $\mathrm{M}_{3} や$ $\mathrm{A}_{2}$ までは除去しうるので，きれいにすべきである．しか し天幕下の clot は除去することは困難あるいは不可能に 近いものであるが，天幕上の clotに比べて血管攣縮を起 しにくいようにも思われるので助かるとも思われる．しか しこの場合は持続脳室ドレナージは絶対必要である.

さて，我々の vasospasmの実験についても少し述べた い. 最も適している実験動物はネコであり，その脳底動脈 瘤に oxyhemoglobin を滴下して spasmの状況を見るが， 上頸部交感神経節除去と内頸動脈周辺の交感神経剥離術を やった動物では血管攣縮の程度が軽度である。また他の実 験でも，交感神経が血管攣縮に関与していることは明らか である．そこで臨床例の vasospasm ではその症状が重症 になる前に, 上部頸部交感神経節除去と交感神経除去術を やると効果がある. しかし，それと同じような効果を期待 して， $\alpha_{1}$ blockerの投与の実験をやったが，vasospasmが 起こる前に，予防的投与によってそれを予防することがで きた．しかし，起こってからではそれを良くすることがで きなかった．破裂動脈瘤の患者が入院してきた場合には再 破裂を注意するために血圧のコントロールとともに $\alpha_{1}$ blocker も投与している.

しかし，このように厳重な vasospasmのコントロール をやっても clots を十分に除去することができない場合も あり，それを完全に防ぐことはできない，その時には，意 識が悪くなってからでは世界でやられているどんな治療を 行っても手遅れである．意識が悪くならないうちに，麻痺 が軽度な時に治療を行わなければならない。 また，最近で は balloon を頭蓋内血管に進めて inflate して，その力で vasospasm を拡大させていく方法をやってみて，それもか なり有効であると考えられる.

さて，手術適応の決定は根本的な重要な問題である。私 は他の蔵器に合併症がない限り, 患者さんの意識状態, そ してその推移を観察することによって，手術は今やるべき であるというようなことを決断している，すなわち，意識 が悪い場合, 極めて悪い場合, 経過が down hill コースの 場合には，このような時はVDDを行ったり mannitol を 投与したりして up hill コースに持っていって, namecalling に応じないものではもはや operation の適応ではな くなっているものと考える.

まだまだお話しが足りない点もあるが，更に私は術中， 私自身に聞かせていることもある. すなわち嗅覚神経を始 め, 脳神経も勿論, 更に脳実質それ自身をも損傷してはい けない, 動脈瘤は neckで十分な処置をする，その際流入 流出動脈に kink を起こさせてはいけないということであ る.

私の経験の前期と最近の成績を比べると，前期では早期 手術の死亡率は15\%であるが，後者ではそれまで極めて成 績が悪かった 48 時間以内の手術でも死亡率は $6 \%$ となって おり，そして全体として見ても進歩している。

しかし，それまでは mannitol はなぜ血流遮断時間を延 長できるのかということが分からなかったので，私の説得 には迫力がなかった. ある時, mannitol は昔から $\mathrm{OH}$ radical の free radical scavengerであるといわれているこ とに気がつきそして cerebral infarctionの時に free radical reaction が起こるということも動物実験でそれを 証明することができ, mannitol などの scavenger を与え た場合には free radical reactionを押えることも証明する ことができた。すなわち我々の工夫して造った rat の cerebral infarction 動物を用いて chemiluminescence の実 験をやり，その結果 5 分間の ischemia の最中でも photon が出て, infarctionの初期においても, free radical reactionを起こしていることが明らかになり，それに mannitol などの free radical scavengers を与えると, photon の抑制を証明することができて, mannitol は free radical scavengerとして有効であることを証明できた.

また,この世の中には free radical scavenger は mannitol ばかりではなくいろいろな scavengers があるので, それらにも脳保護作用があるのではないかと考えた．先ほ どの犬の実験でそれらの薬効を見たところ，他の scavenger といわれている薬剤にも脳保護の作用があることが分 かった. そして mannitol, vitamin E, steroid の三剂をカ クテルにして用いると極めて良い脳保護作用があることも 分かって，その後はこの三剤のカクテルを手術の際に用い ることになる。 
さて今度は hypoxia の時の脳保護の薬効を判断する実 験に移るが， $4 \% \mathrm{O}_{2} ， 96 \% \mathrm{~N}_{2}$ の気体の中にあらかじめい ろいろの薬荗を注射したマウスを入れたが，多くの場合， 動物は 3 分以内で死亡してしまった。この方法では薬効を 決めることができないと実験を断念したが，しかしその死 亡状況を見るとすべてがてんかん発作を起こして死亡して いることに気がついて，試しに抗てんかん剤のアレビアチ ンを注射して実験した。アレビアチン注射のものではその 気体の中で 1 時間以上も生存することが観察できたのであ る.それで，先程の犬を用いたスケジュールでアレビアチ ンの実験をする。その結果はこれまで使用していた mannitol を始めとする薬剤よりも，しかも単味でも極めてす ぐれた脳保護作用のあることが分かり, mannitol, vita-

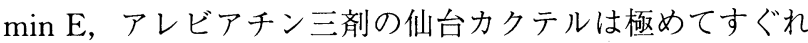
た薬効があるということも分かり，臨床でも使用している

(Table 1).

先ほどの犬の実験で，30\%の ischemia の場合，処置の ないままに 6 時間後 $\mathrm{CBF}$ を $100 \%$ の元に戻しても，脳の 活動は停止したままなのであるが，一方，30\% ischemia の後の30分後に仙台カクテルを投与すると，脳波の消失は なく，6時間後に再開通をすると，脳波の回復は著明にな り，効果は大であった.

一方，ラットの ischemia 5 分の各種の FFA を計ってみ ると，アレビアチンによって FFA が抑制されていること が明らかであり，アレビアチンは脳の ischemiaの変化を 生化学的にも抑えることを明らかにできたのである．さら に，脳浮腫の程度や Evans blue の浸出程度をも極めてア レビアチン単味でも抑制しうることも分かってきており， 1981年以降はこの三剤のカクテルを臨床に用いているので ある。

さて我々脳外科医が動脈瘤の手術で最も恐ろしいことは, 術中の絶望的な破裂である。この状況では動脈瘤の neck の処置することなど到底不可能である. その時はどうして も一時的にも流入流出動脈を遮断しなければならない。そ して dry field で操作を続けなければならない. しかも， その際出血する血液が深部に流れていくことによって spasm が起こったりして予後が悪くなるのであり，できる だけ早くそれを処置しなければならない，私は前にも述べ たが，動脈瘤を剥離する前から流入流出動脈に一時的クリ ップを置いて動脈瘤内の血圧をゼロにしてから手術をする ことが破裂を予防して，確実な，早い手術ができて，これ がいい成績を上げることができる原因と思っている(Fig. 3).

さて，先ほどの犬の実験モデルで仙台カクテルの効果が どれぐらいの虚血の時に，どれぐらいの効果を示すかとい う実験をしてみた。ポンプを停止した場合，血流は $0 \%$ に
Table 1 Permissible occlusion time of cerebral arteries by our method

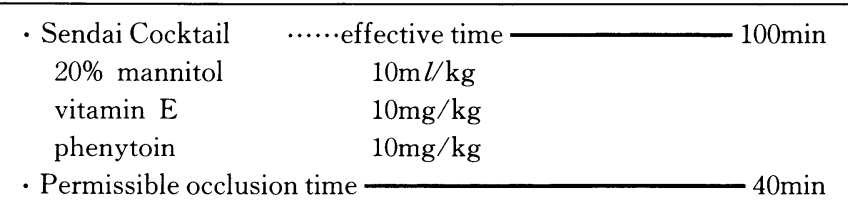

Table 2

\begin{tabular}{lrrrrrr}
\hline \multicolumn{1}{c}{ Site } & $\begin{array}{c}\text { No. of } \\
\text { cases }\end{array}$ & Excellent & Good & Fair & Poor & Dead \\
\hline AcomA & 651 & 406 & 109 & 64 & 39 & $33(5.1 \%)$ \\
ICA & 455 & 286 & 78 & 35 & 32 & $24(5.3 \%)$ \\
MCA & 368 & 225 & 63 & 42 & 26 & $12(3.3 \%)$ \\
ACA & 86 & 61 & 7 & 6 & 8 & $4(4.7 \%)$ \\
V-BA & 68 & 32 & 13 & 7 & 10 & $6(8.8 \%)$ \\
Multiple & 372 & 188 & 83 & 43 & 24 & $34(9.1 \%)$ \\
\hline Total & 2000 & 1198 & 353 & 197 & 139 & $113(5.7 \%)$ \\
\hline \multicolumn{7}{c}{ June, $1961 \sim$ June, 1986. } \\
\hline
\end{tabular}

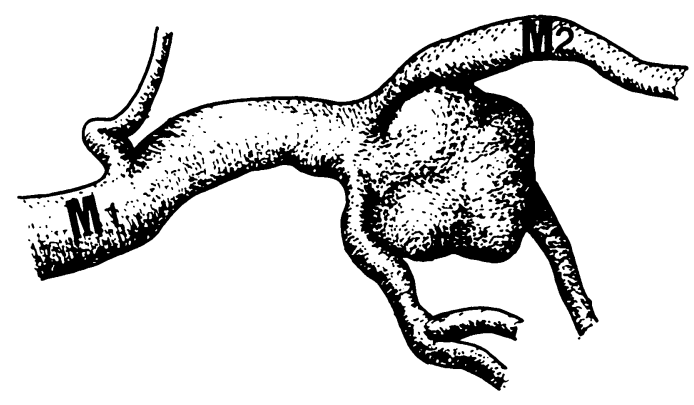

daughter aneurysm

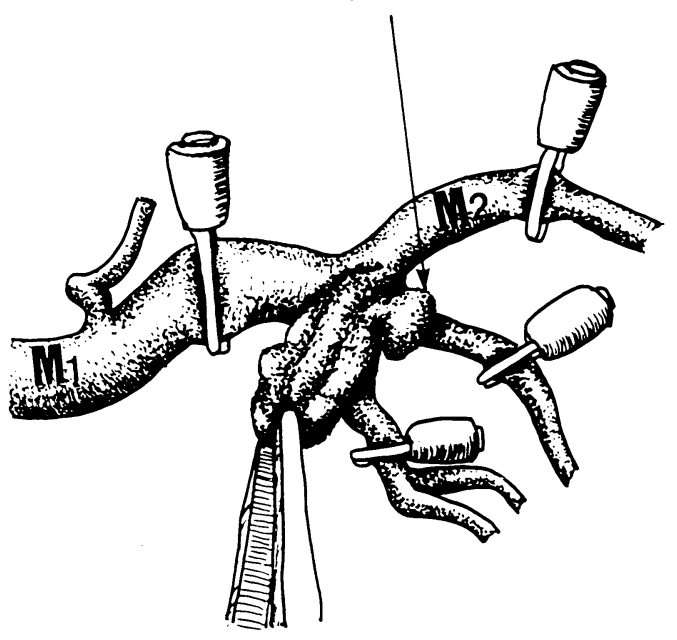

Fig. 3 
なるが，10分で血流を再開しても脳は蘇生しない．仙台力 クテルではそれを20分に延長できる．10\%では20分のもの を 1 時間に延長できる. 30\%では 30 分から 3 時間に延長す ることができ，40\%のときは 1 時間から 6 時間以上に延長 することができる(Fig. 4).

さて, 動脈瘤の手術の場合は, temporary clip やって も血流が $0 \%$ ，あるいは $10 \%$ ということは極めて少ないこ とと思われるので，仙台カクテルを投与し終ってから 100 分以内であれば temporary clip を40分は行いうると, 私は そのようにして多数をあつかっている. temporary clipが さらに長時間必要な時には 5 分間 recirculation して, 100 分以内の時にはさらに40分は遮断できる. 最初の投与から 100分過ぎていればもう一度仙台カクテルを投与すること が必要である。

このように1986年 6 月 9 日に私は個人として 2,900 例の 脳動脈瘤の直達手術を経験した. 勿論, giant aneurysm, multiple aneurysm, 急性期の動脈瘤の手術を含めて, 全 体としての入院中の死亡率は $5.7 \%$ である7) 10) 12). 昨年 の 5 月, Springer-Verlag から出版できた 400 ページの 『Treatment of Cerebral Infarction』という書物に仙台カ クテルのすべてを書いたので，参考にして頂きたい ${ }^{11)}$.

さて, 話が替わるが私の経験では giant aneurysm の処 置は極めて困難である. 特に直接手術の成績は多くの報告 とも手術死亡 $15 \%$ ～ $20 \%$ 以上の高率を示している. 私も残 念ながら同じである.

また, IC giant aneurysmに対する carotid ligation は不 安がある.しかし，それにバイパスを加えた方法ではより 良い成績は得てはいるが, それでも IC bifurcationの giant aneurysmでは必ずしも安心ではない。後に破裂し て死亡したものを経験している.やはり, 将来は balloon を用いて治療する必要がある. IC giant aneurysmに対し ては到達可能であり, aneurysm neck が明らかであるもの では direct surgeryもいいと思うが, non-accessible で sclerosis の強いものはやはり IC の ligation とバイパスを 併用することが無難である.

最近，私が考えた方法をまず動物実験から始めた。臨床 症例は少ないが紹介する. 大腿動脈から長いカテーテルに 導かれた長いラシック balloon を動脈瘤の neck の上と下 をまたがれて setして inflateして neck を塞ぐ. 勿論, 仙 台カクテルを投与する。 また IC の頸部でも血流を遮断し て, 必要であれば頭蓋内の IC をも一時遮断して上下から の balloon にあたる血流をできるだけ小さくして balloon を inflateして aneurysmの内圧をゼロとする。 そしてそ の時, 動脈瘤それ自身を直視下に穿刺して動脈瘤内の血液 を吸引し，代わりにアロン $\alpha$ の少量を注入する. aneurysm は凝固して neck がアロン $\alpha$ で閉塞される.

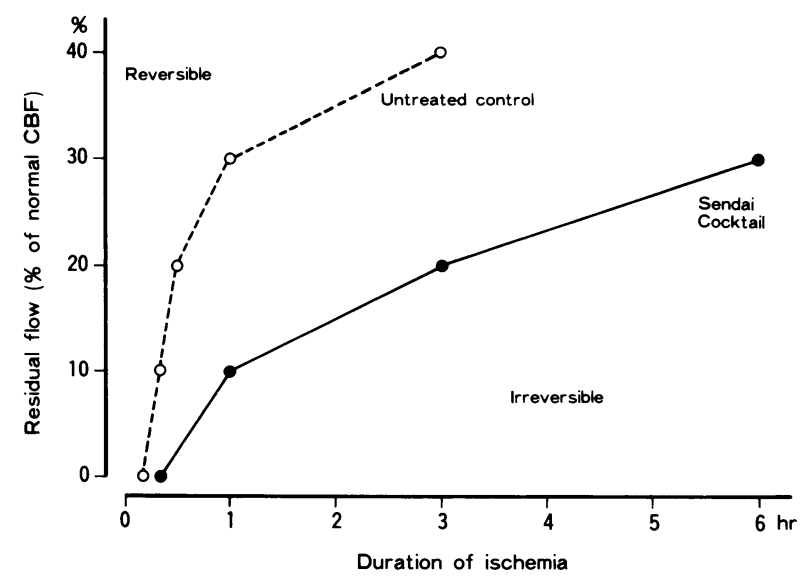

Fig. 4 Functional recovery of ischemic brain as related to degree and duration of ischemia.

balloon d deflate して引抜くと, IC aneurysm は消えてそ のまま patency を保つ. 症例が少ないので今後開拓してい きたいと思っている.

このように今からは困難な動脈瘤に対してはカテーテ ル・バルーンの technique の世界になっていくものと思う が, 現在各地で radiologist が interventional surgery と称 して行っているが, やはり pitfalls が起こるので, これか らは密接な関係をもった neurosurgeon が関係してこれを やっていかなければならないと強く思う.

さて，前交通動脈の giant aneurysm に関しては，私の 直接手術成績が割合にいいので, bifrontal interhemispheric approach で直接手術してもいいと思う.中大脳動 脈の巨大動脈瘤に対しては, 動脈硬化のない, そんなに大 きなものでない場合は直接手術で十分に処置できるが，そ れが neckで $\mathrm{M}_{2}$ が動脈瘤壁に含まれている場合, 無理し て剥離することは危険であり, bodyを切除して, 縫合し て，その周りをアロン $\alpha$ で流入流出動脈を含んですべて をwrapping することも勧められる. しかし, sclerosisの 強い石灰化の起こっているもの，あるいは極めて大きいも のや serpentine aneurysm では direct operation はやらな い方がいい(Fig. 5). これも balloonのほうが結果がいい. しかし動脈瘤の中に balloon が泳いでしまうような balloonは後刻血流と共に瘤内で踊りを踊ることになり，そ れが動脈瘤壁を削って, 破裂を起こしてくることは確かで ある. fitするもの，そして neck を残さないように注意し なければならない(Fig. 6)。また, giant aneurysm は成長 しないものと思われていたが, 放置すればやはり成長して 大きくなり，またその回りのLDA も広がってくる．やは り早く balloonによって動脈瘤を治療することが必要で, それによって LDA も小さくなり症状も良くなる(Fig. 7).

次に, 脳底動脈の giant aneurysm, これは直接手術は 


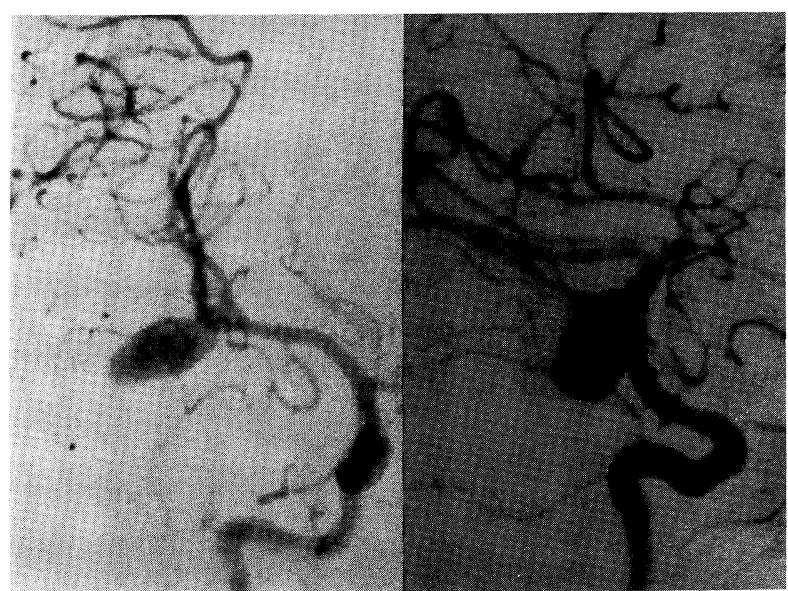

Fig. 5

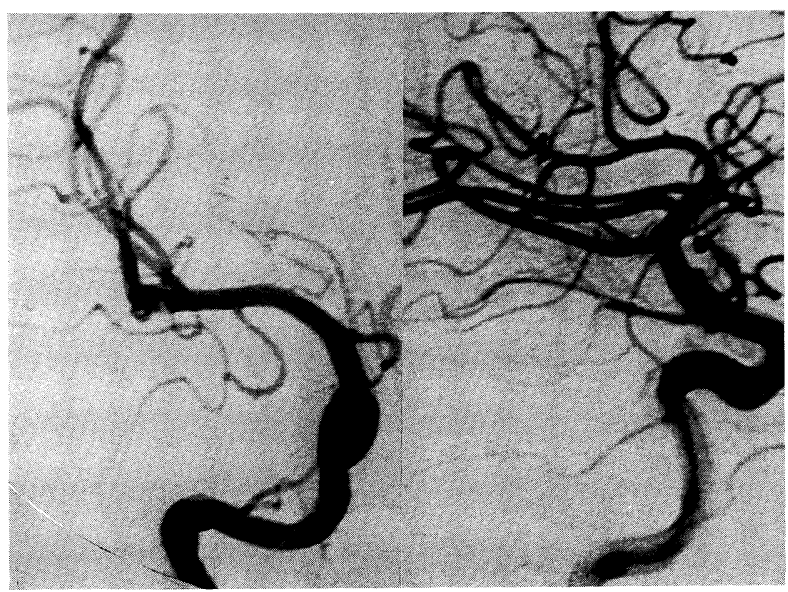

Fig. 6

極めて困難である。これはよほど決心しなければ direct は やってはいけない.やはり大部分のものは例外を除いて balloon を応用してやった方がよい.

この症例は PC-SCの間から発生した giant aneurysm だ が, subtemporal から approach しても trans-sylvian から 入っても巨大な動脈瘤のwall だけが視野を一杯にして流 入流出動脈などは全く見られないと考え, balloonを aneurysm の neckに置いて，仙台カクテル投与のもとに ABR をモニターのもとに手術に入った。やはり動脈瘤壁 以外は何も見えなかったので， balloonによって血流遮断 をして，動脈瘤を削っていって neckだけにして clipに成 功した。このような動脈瘤はやはり仙台カクテルをやって 血流遮断下に手術を必要とする.

最近我々の手術場では CT と DSA を備えた。 そして自 動的にコントロールできる手術台によって CT と血管撮影 を適時に撮影をしている。

さて, subtentorial に発生する dissecans aneurysm の処 置だが, 往々にしてこの部分のものは giant aneurysmに なることがある。その場合は proximalに detachable bal-

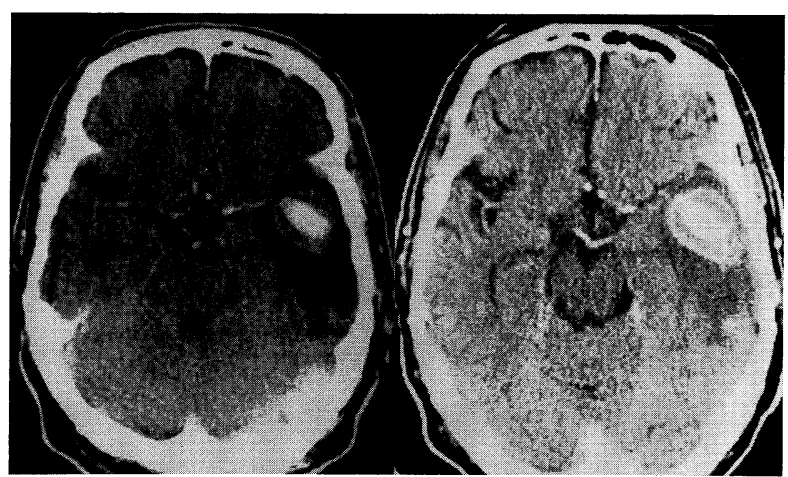

$11 / 23$

$12 / 2$

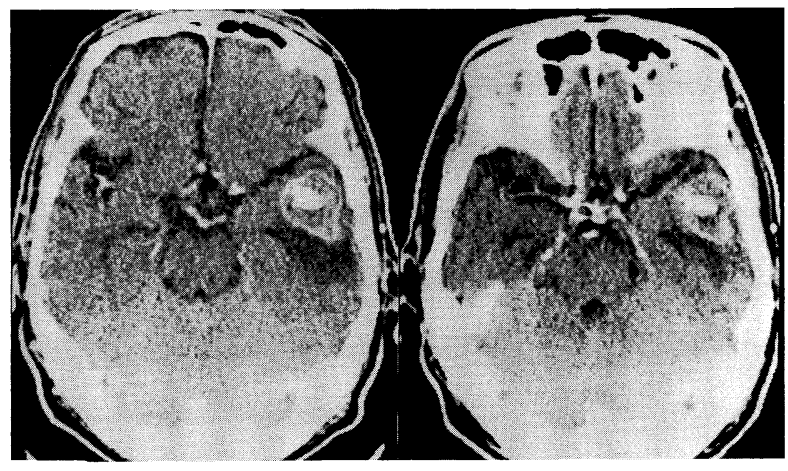

$12 / 22$

$1 / 21$

Fig. 7

loon で治療ができる．直接手術は不必要で，まずMatas testをやって安全であればそのまま balloonをそこに置い てくる．症状も良くなるものが多い.

動脈瘤は縮小して症状も良くなってくる，また， vertebral の dissecans aneurysm の rupture 急性期においても, detachable balloon で Matas test をやった後, 同じ方法で 治療できるが，そのときは完全な vasospasmの対応が必 要となる.

さて, rupture aneurysmの治療に関しては今までいろ いろと述べてきたが，その他多くの人々によって研究され てきたが，今後おそらく rupture aneurysm は破裂後 6 時 間以内は rerupture しやすいので血圧を低くコントロール しておいてその後 CTや angiography を撮り，その間意 識状態を良くする努力をして手術適応であるならば，すぐ に直接手術あるいは balloonの technique を応用して対処 するようになるものと思う。

最後に皆様のお知恵を伺いたいが，このような種類の動 脈瘤の治療は私には今のところの知識や technique でも治 療は非常に困難なものもあると思わざるをえない.

さて最後に，これからはどうしてもいろいろな場合に balloonの technique を応用することになると思うが, balloon technique はあくまでも, 密接な関係にある脳外科医 
の存在ということだけで行うべきものであるということを 強調したい.

\section{文献}

1) Amagasa M, Yoshimoto T, Mizoi K, Suzuki J: Early cerebral angiography after aneurysm rupture. Analysis of 179 cases. J Neurosurg 65: 776-778, 1986

2) Hori S, Suzuki J: Early and late results of intracranial direct surgery of anterior communicating artery aneurysms. J Neurosurg 58: 433-440, 1979

3) Onuma T, Suzuki J: Surgical treatment of giant intracranial aneurysms. J Neurosurg 51: 33-36, 1979

4) Suzuki J, Hori S, Sakurai Y: Intracranial in the neurosurgical clinics in Japan. J Neurosurg 35: 34-39, 1971

5) Suzuki J, Yoshimoto T, Onuma T: Early operations for ruptured intracranial aneurysms. Study of 31 cases operated on within the first four days after aneurysm rupture. Neurol Med Chir(Tokyo) 18: 83-89, 1978

6) Suzuki J: Cerebral Aneurysms-Experiences with 1000
Directly Operated Cases, Neuron Publishing Co., Tokyo, 1979

7) Suzuki J, Onuma $T$ : Intracranial aneurysms associated with arteriovenous malformations. J Neurosurg 50:742-746, 1979

8) Suzuki J, Yoshimoto T, Mizoi K: Preservation of the olfactory tract in bifrontal craniotomy for anterior communicating artery aneurysms, and the functional prognosis. J Neurosurg 54: 342-345, 1981

9) Suzuki J, Yoshimoto T, Kayama T: Surgical treatment of middle cerebral artery aneurysms. J Neurosurg 61: 17-23, 1984

10) Suzuki J, Mizoi K, Yoshimoto T: Bifrontal interhemispheric approach to aneurysms of the anterior communicating artery. J Neurosurg 64: 183-190, 1986

11) Suzuki J: Treatment of Cerebral Infarction. Experimental and Clinical Study, Springer-Verlag, Wien, 1987

12) Yoshimoto T, Uchida K, Suzuki J: Surgical treatment of distal anterior cerebral artery aneurysms. J Neurosurg 50: 40-44, 1979 